\title{
Society and Utopia in Liu Cixin
}

Adrian Thieret

\section{(2) OpenEdition}

\section{Journals}

\section{Electronic version}

URL: http://journals.openedition.org/chinaperspectives/6643

DOI: 10.4000/chinaperspectives.6643

ISSN: 1996-4617

\section{Publisher}

Centre d'étude français sur la Chine contemporaine

\section{Printed version}

Date of publication: 1 March 2015

Number of pages: 33-39

ISSN: 2070-3449

\section{Electronic reference}

Adrian Thieret, « Society and Utopia in Liu Cixin », China Perspectives [Online], 2015/1 | 2015, Online since 01 January 2017, connection on 14 November 2019. URL : http://journals.openedition.org/ chinaperspectives/6643; DOI : 10.4000/chinaperspectives.6643 


\title{
Society and Utopia in Liu Cixin
}

ADRIAN THIERET

\begin{abstract}
This article examines utopianism in contemporary China through the short stories "Taking Care of God" and "Taking Care of Humans" by best-selling science fiction author Liu Cixin. It argues that these stories constitute an ethical resistance to the shortcomings of the capitalist world order into which China has merged during the reform period. Read as a continuation of the modern Chinese utopian tradition as well as a reaction to contemporary trends, these stories offer an articulation of hope that a more just social order can yet be achieved despite the seemingly intractable problems facing the world today.
\end{abstract}

KEYWORDS: utopia, dystopia, science fiction, reform era, globalisation, capitalism.

\section{Introduction}

C ultural critic Li Tuo describes contemporary China as an "era of the petty." (1) In this era, he argues, our lives are defined by consumption, and culture has been reduced to trivial expressions of desire for ever more consumption and wealth. The majority of Chinese writers since the 1990s "benefited from the reforms [of the Deng Xiaoping era], and as such the emotions, dreams, and ideals expressed in [their] writing were naturally those emotions and demands of the social strata that benefited from the reforms." These writers thus consciously or unconsciously reinforce the system of market capitalism and commodification that has taken root in China since Mao's death. Utopian ideals are dead, Li writes; "One cannot even mention objectives of human liberation" without being ridiculed. And "this would be just fine," he points out, "if China did not have several hundred million peasants, tens of millions of retired or laid-off workers, and severe social problems caused by the rapidly increasing disparity of wealth."

Utopianism and its demise in modern China were chronicled 30 years ago by Maurice Meisner, who in Marxism Maoism and Utopianism discusses how Maoism, although it promoted values conducive to modernisation-as-an-end in itself, nonetheless contained a utopian spark of ethical resistance. "Utopia" and "utopianism" here refer not to a perfect place, for such is forever unattainable, but rather to the process of seeking that place. Maoism was "a philosophy which taught that change is an absolute and objective law of history and nature, and at the same time placed an absolute normative value on change and the spirit of change as a way of life." As such, it fought for the socialist dream while resisting "bureaucratic routinisation," "new forms of social inequality which naturally accompany the modern economic development of a backward country," and "general institutionalisation of the postrevolutionary order." (2) Irrespective of its practical failures, Maoism was adamantly utopian in its quest for improvement and resistance to the capitalist trends spreading across the rest of the world. Yet that utopianism died with Mao, and Chinese "socialism" became no more than modernisation, as exemplified by Deng Xiaoping's 1980 declaration: "The purpose of socialism is to make the country rich and strong." "(3) Meisner, writing a few years after Deng Xiaoping had begun China's Reform and Opening, starts his book with a powerful indictment of post-Mao China as well as all modern civilisations. First repeating Frank and Fritzie Manuel's lament over "the discrepancy between the piling up of technological and scientific instrumentalities for making all things possible, and the pitiable poverty of goals" in Western society, Meisner writes, "no less pitiful is the im- poverishment of goals in Communist-ruled lands....Marxist visions of a communist utopia have given way to the goals of modern economic development and official Marxist-Leninist doctrines, correspondingly, have degenerated into little more than ideologies of modernisation." (4) As Li Tuo argues in the Chinese context, ideals of human freedom have been forgotten today as people revel in the material rewards of their individual labours.

The social inequity that Li Tuo deplores in China is but one of many interrelated problems such as widespread wars, financial crisis, social injustice, and environmental degradation (all disproportionately affecting the poor) that arise from the current world system of which China is now an inextricable part. Today we expect and indeed depend upon incremental technological improvements in our lives, for the current ideology of technological optimism promises that new band-aids will continually be invented to patch particular problems as they arise. However, that particular brand of modern utopianism quickly turns to dystopia in its realisation, for it offers only more of the same. Even as technology temporarily sates the need for constant expansion demanded by our socioeconomic structure, the idea that technology will eventually solve all problems merely serves to gloss over the contradictions that arise between the structure of the global capitalist system, human needs, and environmental limits. Although particular problems are felt more acutely in certain regions, the causes and effects are both inherently global. This web of interaction has been elucidated by Ulrich Beck, whose work in understanding the contemporary "world risk society" has led him to the conclusion that the various catastrophes we confront today all "must be understood as consequences, acts and uncertainties that are produced by civilisation," and must be dealt with accordingly, as problems arising from the structure of global society. ${ }^{(5)}$

Fredric Jameson addresses the contemporary world system and its ideology directly, arguing that the disappearance of utopia from the political and

1. This and the following quotes are from Li Tuo and Yan Lianke, "Enjoyment: A New Experiment on Surrealist Writing: A Dialogue between Li Tuo and Yan Lianke," in Xueping Zhong and Ban Wang (eds), Debating the Socialist Legacy and Capitalist Globalisation in China, Palgrave Macmillian, 2014, pp. 151-162.

2. Maurice Meisner, Marxism Maoism and Utopianism, Madison, University of Wisconsin Press, 1982, pp. 208-209.

3. Ibid., p. 238.

4. Ibid., pp. x-xi.

5. Ulrich Beck, "Critical Theory of World Risk Society," Constellations, Vol. 16, No. 1, 2009, p. 15. Beck does not argue for an entirely new system, however. That capitalism in particular is the problem is an implicit premise of the utopianists such as Jameson and also convincingly argued by Marxian social scientists John Bellamy Foster, Brett Clark, and Richard York in The Ecological Rift: Capitalism's War on the Earth, New York, Monthly Review Press, 2010. 
economic realms and our everyday experience was caused by the ascension of capitalism to practically unchallenged world hegemony following the failure of socialist practice: "What is crippling [today] is not the presence of an enemy but rather the universal belief, not only that this tendency [toward capitalism] is irreversible, but that the historic alternatives to capitalism have been proven unviable and impossible, and that no other socioeconomic system is conceivable, let alone practically available." (6) Under these circumstances, as Jameson argues, radical social change requires "the forcible reopening of access to a sense of society as a totality, and of the reinvention of possibilities of cognition and perception that allow social phenomena once again to become transparent, as moments of the struggle between classes." (7)

It is in this context that the utopian imaginations of literature can help us grasp the relevance of the overall system to our individual lives because it is not strictly bound by the rules of reality under which we live our everyday lives, and can reveal everyday experience "as a function of the commodity system and the reifying structure of late capitalism, thus exposing that structure as contingent, a moment in history rather than the end of history." " ${ }^{8)}$ Along these lines, Li Tuo locates an ethically productive utopianism in the surrealist literature of Yan Lianke, who tries to grasp the fragmentary world and its problems through satires of modern society focused on the downsides of the market reforms and the plight of the lower classes in China today. However, surrealism is not the only option.

This article examines the utopian potential of contemporary Chinese science fiction (SF) literature in view of the problems faced by Chinese and world society today. Beginning from the premise that utopianism is a necessary ethical force and an indispensable driver of human history - as MaxWeber observed, "Man would not have attained the possible unless time and again he had reached out for the impossible" (9) - I argue here that the works of Liu Cixin, the most popular Chinese SF author thus far to emerge in the new millennium, offer utopian threads of hope for a new, more ethical social order in face of the often dystopian realities of contemporary China and the world. This is supported in the following pages through a close reading of two of his stories, "Taking Care of God" and "Taking Care of Humans," as products of and reactions against contemporary reality, in particular to the global crises of social inequality and ecological destruction that threaten the globe.

\section{Science Fiction, Utopia, and China}

When imported from the West by Liang Qichao and other early modern intellectuals at the beginning of the twentieth century, science fiction in China "was constituted as a utopian genre that could provide both reflection on reality and hope for change." (10) Literature has long been considered an instrument of social criticism and reform in China: for two thousand years the Confucian tradition championed literature as a way to teach correct morality, and in modern times the May Fourth Movement and Communist revolution both also burdened literature with responsibility for radically changing Chinese society. As an intellectual educated in the Confucian tradition who sought to reform and modernise China around the beginning of the twentieth century, Liang Qichao believed that science fiction was not merely a literature of science and modernisation; rather, it was a philosophical literature that had a role to play in "renovating the people's minds" and creating the new ethical world citizen. ${ }^{(11)}$

Liang demonstrated his hopes for science fiction, and particularly for the role it could play in making a better China and better world, in attempting to write his aborted novel The Future of New China (serialised in 1902), which depicts a utopian future in which China has risen up to equal status with the Western powers, and the world has achieved peace. The same year, Liang's hopes for SF found further expression in "Record of the Last Days of the Earth" (Shijie mori ji), his translation of a short story by French astronomer Camille Flammarion that scientifically narrates the progression of both human civilisation and geologic history into the far future. In his translator's afterword, Liang praised the short story as built of "the most precise of scientific principles and the most noble of philosophic ideals." (12) He calls it a "philosophical-scientific fiction," a type of work that "uses the form of fiction to elucidate philosophy and science." Liang's other examples of this form include The Republic of Plato, Yano Fumio's The New Society (Shin Shakai, a 1902 account of socialist utopia), and Verne's Around the Moon. ${ }^{(13)}$ Liang praised these works not for scientific facts, but for the scientific mindset exhibited therein. These works of "philosophical-scientific fiction" could convey modern science and rational thought, which were necessary to empower the Chinese people and push the world forward out of international conflict toward peace and prosperity.

Liang Qichao's promotion of science fiction was heard by many, including the young student Lu Xun. It is well known from Lu Xun's preface to Nahan that he turned toward modern science following his father's death at the hands of traditional Chinese medicine practitioners, and subsequently turned from medical practice itself toward literature as a way to promote changes in the Chinese mindset. Less well known is that over a decade earlier, while still a student of medicine in Japan, Lu was already engaged in this literary practice as he translated two novels of Jules Verne from Japanese into classical Chinese. ${ }^{(14)}$ In Lu Xun's preface to his 1903 translation of From the Earth to the Moon, which although published the year after Liang Qichao's foundational works had been deemed the "first theoretical article on Chinese SF," (15) he explains that science fiction can help readers understand and absorb science by dressing up dull scientific ideas in the attractive trappings of fiction, and thereby help the Chinese people modernise. ${ }^{(16)}$

6. Fredric Jameson, Archaeologies of the Future, London, Verso, 2005, p. xii.

7. Fredric Jameson, "Reflections in Conclusion," in Bloch et al., Aesthetics and Politics, London, Verso, 1980, p. 212.

8. Ibid., p. 213.

9. Quoted in Maurice Meisner, Marxism Maoism and Utopianism, op. cit., p. 4.

10. Mingwei Song, "Variations on Utopia in Contemporary Chinese Science Fiction," Science Fiction Studies, Vol. 40, No. 1, 2013, p. 86.

11. Liang's well-known thesis of the power of literature is articulated in his 1902 essay "On the Relationship between Fiction and the Government of the People," in Kirk Denton, Modern Chinese Literary Thought, Stanford University Press, 1996, pp. 74-81. Ban Wang analyses Liang's vision of a new ethical world order in "Ceopolitics, Moral Reform, and Poetic Internationalism: Liang Qichao's The Future of New China," Frontier of Literary Studies in China, Vol. 6, No. 1, 2012, pp. 218.

12. "Shijie mori ji yi hou yu" (Afterword to "Record of the last days of the Earth"), originally printed in Xin xiaoshuo in 1902 under the pen name of Yin Bing, is reprinted in Chen Pingyuan and Xia Xiaohong, Ershi shiji Zhongguo xiaoshuo lilun ziliao (Theoretical documents on Chinese novels of the 20th century), Vol. 1, Beijing daxue chubanshe, 1989, pp. 40-41.

13. "Zhongguo weiyi zhi wenxuebao Xin xiaoshuo" (China's only literature journal, New Fiction), in Chen Pingyuan and Xia Xiaohong, Ershi shiji Zhongguo xiaoshuo lilun ziliao, op. cit., p. 45.

14. Although resources in English are limited, for more on Liang Qichao and Lu Xun's engagement with SF, the reader may wish to consult the overview of early Chinese SF by Nathaniel Isaacson, "Science Fiction for the Nation," Science Fiction Studies, Vol. 40, No. 1, 2013, pp. 33-54.

15. For example, Wang Quangen says this in Xiandai Zhongguo kehuan wenxue zhuchao (Main currents of modern Chinese science fiction literature), Chongqing chubanshe, 2010. Jonathan Spence over 30 years ago observed that Lu Xun's views on science fiction were influenced by Liang Qichao: see Jonathan Spence, The Gate of Heavenly Peace, Penguin Books, 1982, p. 65.

16. Lu Xun, "Yuejie lüxing bianyan" ("Introduction to From the Earth to the Moon"), in Lu Xun yiwen quanji, Vol. 1, Fujian jiaoyu chubanshe, 2008, pp. 5-6. 
Following the work of Liang Qichao and Lu Xun, many Chinese intellectuals created or commented on works of science fiction in the first decades of the twentieth century. The central concern underlying most of these works, such as Huangjiang Diaosou's Tales of the Moon Colony (Yueqiu zhimindi, 1904), Lu Shi'e's New China (Xin Zhongguo, 1910), and Lao She's Cat Country (Mao cheng ji, 1932), is stated plainly in the title of Liang Qichao's novel: The Future of New China. Nathaniel Isaacson correctly reminds us, however, that we must not think SF special in this regard: the future of China is one of "the thematic concerns... [that has] remained central to modern Chinese literature" since the late Qing. (17) There is much that could be said about the depictions of technological and socialist utopias envisioned by Chinese science fiction under Mao as well, but an analysis of these eras is beyond the purview of the present article. Our goal in these few paragraphs has been merely to establish the link between the beginnings of science fiction in China and the genre's engagement with utopian thought that both reflects critically on the present conditions of society and envisions alternative possibilities for the future.

The context of Chinese science fiction today is far different from that of a century ago: China no longer faces real threats of imperial domination (although the rhetoric of such threats still plays a role in the CCP's endeavours to shore up its own legitimacy, and such fears also persist in sections of the cultural imaginary). China's continued national sovereignty, wealth, and power are practically assured, and now it confronts the same problems of social inequality and ecological collapse that threaten all humanity. Literature too is different: whereas Liang and Lu enjoyed the utopian worlds of Jules Verne, Camille Flammarion, and Edward Bellamy, and Liang attempted to write his own future utopia in The Future of New China, Chinese science fiction today more often (though by no means exclusively) depicts dystopias. Chinese SF writing began to flourish anew following Reform and Opening, and the most popular writers today, Han Song, Wang Jinkang, and Liu Cixin, as well as numerous younger up-and-coming authors, write of dystopian futures like their Western counterparts in which one or more of the trends of modern society is glaringly exposed, along with related social collapse and acute crisis. Yet the utopian impulse underlying these contemporary Chinese dystopias is similar to that which inspired Liang's utopian thinking and led Lu Xun to scratch at the walls of the iron house with his pen: the contemporary writers share the ethical concern of their early twentieth century forebears for the state of society, and reflect and fight social ills through their literature.

In the contemporary context of globalisation, with China as a newly risen technological and economic superpower, SF in China has come to share much with SF originating elsewhere even while remaining distinctly Chinese. China's top SF magazine, Kehuan shijie, publishes regular issues dedicated to translated works, and current Chinese SF authors admit heavy influence from foreign SF writers - Liu Cixin cites Arthur C. Clarke as his main inspiration, for example. ${ }^{(18)}$ Chinese SF critics today also engage with and adapt the theories of Western scholars in the Chinese context. Any analysis of contemporary Chinese SF, therefore, should account for the theoretical discussions of the genre or mode as a global phenomenon, in addition to accounting for the particularities of its Chinese manifestation. We need not delve deeply into theories of science fiction and utopian literature here, but a few comments are in order. ${ }^{(19)}$

Due to its themes and forms, science fiction literature seems uniquely well suited to expressing utopian imagination in the (post)modern age of global capitalism, in which technology has increasingly come to permeate and define our lives. The formal characteristics of the science fiction genre have been most famously defined as "cognitive estrangement." (20) "Estrangement," refers to the presence of a "novum," meaning something novel that differentiates the fictional world from our own and hence "estranges" it from us and our reality. This novum opens the door for utopian rumination on "radical difference" and reflection back on current reality. In science fiction, unlike other fantastic literatures, the estrangement is "cognitive": the fictional nova of the story are expected to be internally coherent and logically (scientifically) reasoned out, even if they are things that do not or cannot exist in reality. This scientific framework gives SF an aura of plausibility and makes it closer and potentially more relevant to real problem solving even as the novum sets it apart from reality. Furthermore, science fiction tends to be concerned with the effects of technology on society, including how technology has broken down traditional barriers of time, distance, and national borders, and has changed the relationship between humans and our environment. These themes and formal features, combined with science fiction's preoccupation with the future, allow for the imagining of various possible futures, consideration of what futures we might desire or not desire, and contemplation of what actions we should take in the present to attain or avoid those futures. In other words, through depiction of cognitively-reasoned possible futures, science fiction allows us to apprehend our present moment as a transient part of history and offers the future as not fixed but indeterminate and open to the possibility of change. By defamiliarising the present in this way, as Jameson argues, science fiction "enacts and enables a structurally unique 'method' of apprehending the present as history, and this is so irrespective of the 'pessimism' or 'optimism' of the imaginary future world which is the pretext for that defamiliarisation." (21) George Orwell's 1984 provides an enduring example of utopian science fiction in its presentation of a "what-if" scenario based on extrapolation from totalitarian tendencies and surveillance technologies that Orwell witnessed in his present. 1984 warns that the present could lead to its dystopian future (become the past of this future) if we do not take measures to prevent the development. The story follows Tom Moylan's model of the dystopia: it depicts a society markedly worse than reality, and reveals through the conflict between Winston's life and the socio-political system how individual experience is entangled with the entire system. (22) 1984 , like other dystopian fiction, thus brings into relief the social structure itself as deeply flawed, as a construct that can be resisted, presenting a "totalising interrogation" of reality that "refuses a functionalist or reformist perspective," and, having denied simple solutions to the problems plaguing the individual, opens a way for utopian imagination of alternative systems. ${ }^{(23)}$ For although it shows a dystopian world, 1984 proves utopian in two crucial respects: in its depiction of the regime as something contingent that can be resisted, and in how its narrative is framed by the footnotes and appendix as the history of a past regime that

17. Nathaniel Isaacson, "Science Fiction for the Nation," op. cit., p. 33.

18. Liu Cixin, "Beyond Narcissism: What Science Fiction Can Offer Literature," Science Fiction Studies, Vol. 40, No. 1, 2013, pp. 22-32.

19. Those interested in delving further into the connections between science fiction and utopia may begin with the following works: Darko Suvin, Metamorphoses of Science Fiction, New Haven, Yale, 1979, especially the introduction and first chapter; Raymond Williams, "Utopia and Science Fiction," Science Fiction Studies, No. 5, 1978, pp. 203-214; Jameson's works cited above; Andrew Milner, Locating Science Fiction, Liverpool, Liverpool University Press, 2012; Istvan Csiscery-Roney's "Marxist theory and science fiction," in the Cambridge Companion to Science Fiction, Cambridge University Press, 2003, pp. 113-124

20. Darko Suvin, Metamorphoses, op. cit., Introduction and Chapter 1.

21. Fredric Jameson, Archaeologies of the Future, op. cit., p. 288.

22. Tom Moylan, Scraps of Untainted Sky, Boulder, Westview Press, 2000, p. xii.

23. Ibid. 
has been overcome. This frame implies that the regime must have been toppled, and hence even while not specifying what replaced it, offers hope that the future can turn out better. The novel thus provides one example of how dystopian worlds in science fiction can manifest utopian hope even while illustrating pessimistic possibilities of our future fate.

The two dystopian stories of Liu Cixin examined below also evince an undercurrent of utopianism. Liu, who began publishing short fiction in the late 1990s, rose to fame with the publication of his Three Body trilogy (Santi, 2006-2010), his longest and most acclaimed work to date. He has won numerous SF awards in China and received mainstream recognition in 2012 when the journal People's Literature republished four of his stories (including "Taking Care of God"). (24) Liu is a frequent and highly-sought contributor to public discussion of scientific innovation and science fiction and has become a celebrity figurehead of the SF renaissance in contemporary China. Many of Liu's stories have been translated into English, including the Three Body trilogy, the first book of which was published by major US science fiction and fantasy press Tor in 2014. The Three Body trilogy has reportedly sold more than 500,000 copies in China since the final instalment was published in 2010, making it the top selling work of Chinese SF. (25) Yet that is not enough to make Three Body a mainstream bestseller: science fiction, domestic and foreign both, remains absent from the retail bestseller lists of fiction in China, which remain dominated by commercial favourites Guo jingming and $\mathrm{Han} \mathrm{Han}$, translations of foreign works, and canonised literary veterans such as Yu Hua and Mo Yan. ${ }^{(26)}$ We thus approach Liu's fiction as extremely popular and representative within the world of Chinese SF, while recognising that it has not attained the wide popularity and cultural cachet enjoyed by mainstream fiction authors.

Liu Cixin's fiction primarily attends to universal problems such as issues of social inequality, ecological limits, and scientific development that concern humanity on the whole (in contrast to Han Song, for example, whose stories often revolve around conflict between nations and evince deep anxieties about the Chinese nation). Most of Liu's stories take it as given that a strong and powerful China is here to stay. Thus, although he continues the legacy of socially active and didactic science fiction that began in China with Liang Qichao and Lu Xun a century ago, Liu's fiction reflects the very different circumstances of the world today. It is a world in which, at least for Liu, the reality of worldwide risks demands far greater attention than any perceived risks to the Chinese nation. Or, from a different perspective, one could say that this is because China and the world face the same risks in the contemporary world. The two stories examined in the following pages deal with such risks, confronting the contradictions in our civilisation and offering hope that disaster may yet be averted.

\section{"Taking Care of God"}

"Taking Care of God" (2005) is not the typical alien invasion story: the aliens come not to exploit or destroy Earth, but to beg for help. ${ }^{(27)}$ The story signals its fantastic character with the first line, "Once again, God had upset Qiusheng's family," yet our immediate expectations are overturned as the next lines describe a domestic scene in a Chinese village not so remote from those of today. Rather than an omnipotent being manipulating Qiusheng's fate, God has given way to humans and assumed a subordinate position. An old man under the care of Qiusheng's family, God is incapable of even daily chores. For example, he does not turn off the gas after heating himself some milk in the morning.
The quotidian concerns of the Chinese people today come through as we learn about God's relationship with the family. The milk comes from their own cow, and the portion they do not need they, "imitating others, [adulterate] the milk with water to sell" on the market. God did not "forget" to turn off the gas: he assumed it would turn off automatically, for apparently he is accustomed to technological automation of everyday tasks. As Qiusheng complains to God about the incident, he reveals that his family is struggling to meet their material needs: "We aren't like you, being waited on hand and foot by smart machines. We have to work hard...that's how we put rice in our bowls." His wife, Yulian, lodges a similar complaint about material poverty, telling God, "Don't use detergent if there's no grease on the bowl! Everything costs money. The pittance they pay for your support? Ha!"

Neither God nor Qiusheng's family is happy with the living arrangement, as we learn at the end of the first section when God sighs, "How could life have turned out like this?" The narrator tells us that the sentiment is shared by the other members of the family and everyone else on earth, human and Cod. The section thus returns to where it began with the invocation of "Cod" in the first line: it is indeed a cosmic tale, but one intimately concerned with the dialectical relationship between the particular and the universal. The story continues to switch back and forth between narration of the Gods, who all look identical and "do not appear to belong to any particular race, as though all ethnicities were mixed in them," and the life of Qiusheng's family in rural China, and unfolds as an encounter between seasoned veterans of technological optimism who have gradually realised the follies of that path, and the naive humans who are just starting down it, still full of unwarranted hope.

The God Civilisation came to earth three years ago and spread their spaceships around the planet, illuminating the whole world like a "giant surgical lamp." This functions as a bit of meta-fictional foreshadowing for what the gods, as the primary "novum" estranging the story from our reality, reveal about human civilisation today. Before their arrival on earth, the Cods moved from their home planet to the more stable, comfortable ecology of their spaceships, where for millennia they enjoyed a seemingly self-sustaining utopia of complete material prosperity, equality, and bliss. But after they achieved the post-scarcity utopia, development stopped. With nothing left to strive for and no impetus to change, change itself ceased among their civilisation. While occupying themselves with the boundless pleasures of their utopia, the Gods gradually forgot how to operate and build the machines they themselves had created. However, they could not freeze time: the physical laws of the universe continued to operate, and their self-maintaining spaceships, which they had treated as eternal, eventually began to fail. Originally the God civilisation had left its planet and moved to spaceships because "no planetary environment is as stable as a sealed spaceship." But even the isolated environment of the spaceship is not totally isolated. It remains part of the ecosystem of the universe and cannot escape the second

24. Renmin wenxue (People's Literature), No. 3, 2012. The stories republished there are "Shanyang shangdi (Taking Care of Cod)," "Wei jiyuan (Micro-Era)," "Shiyun (Poetry Cloud)," and "Mengzhihai (Sea of Dreams)."

25. Amy Qin, "In a Topsy-Turvy World, China Warms to Sci-Fi," The New York Times, 10 November 2014, www.nytimes.com/2014/11/11/books/liu-cixins-the-three-body-problem-is-published-inus.html (accessed on 11 November 2014).

26. See Open Book's yearly top-30 lists of bestselling retail fiction books (Xugou lei changxiao shupai hangbang) from 2010 onward that are freely accessible online at openbook.com.cn (accessed on 11 November 2014)

27. "Shanyang shangdi" (Taking Care of God), in Liu Cixin, Xiangcun jiaoshi (Village Schoolteacher), Changjiang wenyi chubanshe, 2013. All quotes used here are from the English translation by Ken Liu in Pathlight, No. 1, 2012 
law of thermodynamics. Eventually even its spaceships began to break down as tiny errors accumulated, leading the God Civilisation to create copies of Earth and plant the seeds of human civilisation, planning to come back millennia later, once civilisations have grown up on the planets, and ask for help.

The two billion Gods convince humanity to care for them by offering to give humanity their repositories of scientific knowledge. Despite the Gods' warnings that "everything in the universe" ages and dies, "even the universe itself," which contradicts the UN Secretary General's conviction that human civilisation, "currently in a stage of rapid development," will continue "indefinitely," the humans remain steadfast believers in technology as a solution and end in itself. Humans are elated to receive the Gods' knowledge in exchange for taking care of them. As Yulian exclaims when the God first arrives at their home, "I hear that the technology you gave us will soon allow us to experience true communism! When that happens, we'll all have things according to our needs. Things won't cost any money. You'll just go to the store and pick them up." God replies, "Yes. Actually 'to each according to need' fulfils only the most basic needs of a civilisation. The technology we gave you will bring you a life of prosperity and comfort surpassing your imagination."

Humans initially think that the Gods' technology "would allow mankind to realize their dreams overnight," and they look to it for energy solutions as "the exhaustion of petroleum supplies loom[s] over the human race." The Cods' energy technology cannot solve this problem of human society, however, because it is so far beyond the technology of human civilisation it proves impossible to understand and implement. "The human race was like a group of new elementary school students who were suddenly required to master the material of a PhD candidate, and were given no instructor." This quickly leads to resentment on both the individual and societal levels. Qiusheng's wife, "after the death of her dream of true communism," nostalgically romanticises the time before Cod came as a prosperous era when "everything was good." But the reality is that since God came, she has used the government support stipend for God to buy her family a milk cow, propane fuel in place of coal briquettes, and "a big new color TV." This increase in material prosperity, however, does not bring her happiness; in fact, she forgets it and feels only the burden of dealing with her new, infirm family member.

Both the Chinese villager's misunderstanding of "communism" as a consumerist paradise where all goods are free, and the God's addendum that technology will bring a "life of prosperity and comfort" reflect the aforementioned lack of utopian ideals in contemporary society. The former case may be seen as a reflection of post-Mao Chinese policy, in which "the ultimate goal of all [China's] revolutionary struggle is to liberate and develop the productive forces...to raise the material standards of all the people"; (28) or, as Deng Xiaoping said, "development is the fast imperative" (fazhan cai shi ying daoli). (29) The God's assertion reflects the general tenor of technological optimism that pervades society today. The original socialist goal of human freedom, to which modernisation was the means, is notably absent (capitalism, of course, never had goals beyond the material anyway). Technological modernisation itself has become the ends, and humans cannot see beyond incremental improvements in their lot due to technological advances.

Although their technology is useless to humanity, the Gods have one thing to offer: experience. The Gods lived passively in their paradise, never fully realising that it was slowly, inevitably decaying along with the universe outside. Despite the foresight exhibited by its seeding of planets with human races created in its own image, as caretakers for it in old age, the God Civilisation forgot that those civilisations would have agency of their own, and perhaps be unwilling or unable to host their creators. As human civilisation proves unable to support the Gods, strife erupts around the world as shown in the first scene with Qiusheng's family, and the Gods are forced to reboard their spaceships and leave.

As the God Civilisation leaves Earth, it urges humans to two actions: first, to develop space travel and explore the universe. The Cods themselves show dynamism: as the representative of the God civilisation leaves the Chinese village that hosted him, he takes the high school math, physics, and chemistry textbooks of his host Qiusheng "to study. I'll start with quadratic equations. In the long years ahead, I need some way to occupy myself. Who knows? Maybe one day, I'll try to repair our ships' antimatter engines, and allow us to fly close to the speed of light again!" Qiusheng suggests that the God might thus eventually be able to create another civilisation to support itself. But the God claims that he merely wants to be reunited with his lover on the other side of the universe: "No, no, no. We're no longer interested in being supported in our old age. If it's time for us to die, we die. I want to study because I have a final wish...I want to see her again...In this universe, as long as you're patient, you can make any wish come true. The possibility may be minuscule, but it is not nonexistent."

The God's act of taking the textbooks to study and relearn his technology contradicts the expressed fatalism. As the God's actions unconsciously reject his own statement "if it's time for us to die, we die," he affirms the power of that evolutionary drive for survival. The Gods thought they had achieved utopia by developing technology that supplied all possible physical and mental needs. When the illusion was broken by the immanent breakdown of their spaceship ecosystems, the Gods awoke from their technologicallyinduced stupor to find themselves still mortal, still facing eventual death. This realisation roused the dormant utopian impulse within the God civilisation and drove it to create Earths to care for it in old age. The same desire for immortality is what now drives this particular God to want to fix the spaceships to continue living. Further emphasising how deeply rooted the desire is, the God goes as far to suggest that his civilisation might now accelerate to near the speed of light, slowing time for it relative to the rest of the universe, so it can survive until the end of the universe and this particular God can reunite with his lover.

The final line of "Taking Care of God," "The human race needs to start thinking about who is going to support us in our old age," would seem to belie any utopian hope with its implicit promise of impotence and death. Are we to give up, or to seek a saviour, rather than helping ourselves? These words of Qiusheng's father, arising out of his epiphany that the human race exists as part of the greater universe, also function as a warning against complacency and form a utopian tension with the experiences and action of the God civilisation. For the story itself contradicts his statement, seeming to answer through depiction of the God civilisation's failed attempt at solving that same problem that there are no saviours; the human race must find a way to support itself. The remaining choice, between giving up and actively striving for survival, is not presented as a choice at all.

The ultimate irreconcilability of the story's two propositions as expressed in the words and actions of the Gods and humans at the end: that we contain an evolutionary imperative to survival, and that all efforts at survival

28. Quote from a 1979 article in PRC journal Zhexue yanjiu, cited in Maurice Meisner, Marxism, Maoism and Utopianism, op. cit., p. 234.

29. Deng Xiaoping on his 1992 Southern Tour to the Special Economic Zone of Shenzhen. Deng Xiaoping, "Zai Wuchang, Shenzhen, Zhuhai, Shanghai dengdi de tanhua yaodian" (Excerpts from talks at Wuchang, Shenzhen, Zhuhai, Shanghai, and elsewhere), in Deng Xiaoping wenxuan, Vol. 3, Beijing, Renmin chubanshe, 1994, p. 377. 
are ultimately doomed, is one source of the story's utopianism. For by hoping against hope, refusing despair even while recognising that mortality and entropy being the ultimate principles of our individual lives and universe, the realisation of utopia - conceived as an inherently static, closed, everlasting paradise - is impossible, the story affirms that change and progress are yet possible. "Taking Care of Cod" offers no solutions, either to this problem or to the problems of human civilisation hinted at in the story, such as the energy crisis, poverty, and ecological collapse. Yet as it reveals human existence to be bound by natural law, it exposes the laws of capitalism (or Yulian's "communism") as not laws but artefacts of human civilisation that cannot provide true fulfilment. Human civilisation is exposed as a transitory phenomenon, not a totality after all but a small part of a much larger, dynamic universe. However, this belittling of human civilisation should not be occasion for despair: humanity is not at the mercy of history. Humanity still can and must shape its own future through individual actions, as illustrated in the God's decision to try and reunite with his lover, and in the final words of Qiusheng's father, which we now read not as pessimistic but as a utopian call to action, where utopia is a function of the innate need to adapt to the inexorably changing conditions of the universe.

\section{"Taking Care of Humans"}

"Taking Care of Humans" (2005) is a sort of sequel to "Taking Care of Cod" that builds upon and deepens the latter's critique of contemporary society. ${ }^{(30)}$ As it describes other aspects of the human world, it introduces into the mix another alien world that, like the God civilisation in "Taking Care of Cod," represents a possible future of humankind.

"Taking Care of Humans" likewise begins in the everyday. The protagonist is an assassin who, experiencing doubts over the unusual nature of his new contract, attempts to find reassurance in the principle of his profession: "Work is just work; nothing else matters," and thinks of his instructor's dictum that it is in the best interests of all that assassins should never meet their clients face to face. The reification of human labour and relations that mark the assassin's profession here is even emphasised in the protagonist's name, "Smoothbore," for his weapon of choice: a revolver with an unrifled barrel. He is not a human but a tool, trained to "turn himself into a gun" and "realise the function of a gun." The target of this human weapon, moreover, "is not the weapon's business" but that of the client who has hired it. This denial of personal agency is called the assassin's "most fundamental professional moral." Despite the assassin's attempts to subordinate his human subjectivity, the reification is not total. The assassin's moral subjectivity gradually returns as he carries out his contract, the nature of which is revealed slowly over the course of the story.

Three years after the God civilisation departs, another of the civilisations created by the Gods in their attempt to foster filial children has come to take over the Earth. This civilisation, the "Elder Brothers" of humans, has been forced off its home planet after capitalism ran amok and concentrated the entirety of the world's resources in the hands of a single man. The Elder Brothers had the technological means to create a post-scarcity utopia such as the Cods briefly enjoyed in their spaceships. Yet, rather than use the technology to eradicate suffering, the rich leaders of society used it to eliminate the need for the underclass altogether, and abandoned the poor to their own very limited devices. The extreme disparity of wealth led to irreconcilable division as the wealthy became a different species through education and technological enhancements only they could afford.
Eventually the extreme disparity of wealth proved untenable for all concerned. The rich owned the rights to essentially all the resources of the planet, and members of the underclass were dying as they could not afford to pay for the use of air and water. If the God civilisation of "Taking Care of Cod" illustrates that a post-scarcity egalitarian society alone is not utopia per se, the Elder Brothers here depict the dangers of unchecked privatisation and accumulation of wealth. In their world, privatisation of the shared ecological resources that everyone depends upon for existence effectively deprived the poor majority of their right to live. The man who comes to own the entire home world of the Elder Brothers, confronted with the possibility of revolution and sick of having the poor around, builds them spaceships and exiles them from his planet. They come to Earth.

When the Elder Brothers arrive, the Earth has been overrun by consumerism, and a large underclass of scavengers lives off the trash of the rich. The description of the assassin's targets scavenging perfectly good food, clothing, and shoes from mounds of trash evokes scenes replaying in China and much of the world today as the poor make a living off the scraps of the rich. The Elder Brothers plan to claim most of Earth for themselves and use Australia as a reservation for all humans. However, as the story notes with some irony, their intentions toward humanity are not entirely malicious: even as they repeat the seizure of shared resources that drove them from their home planet, they intend to save humanity from the same extreme progression of capitalism that destroyed their home civilisation. After confining everyone to Australia, the Elder Brothers' technology will provide them with everything they need for a minimum quality of life. Indeed, the Elder Brothers' plan is quite equitable and "the reservation would be a paradise for humanity," as all would be provided with a minimum standard of living.

In order that human civilisation not meet the same fate that the Elder Brothers did when their disparity of wealth reached extremes, the provided living standard is to be determined according to the current minimum standard of wealth among humanity. A group of the richest humans, whose yearly income "could equal the GDP of a mid-size country," organise in reaction to this news. Faced with an immediate threat to their lifestyles, they begin handing out suitcases full of cash to the poor in order to raise the minimum standard. This attempted fix does not address the root cause of social inequality, however: some poor people refuse to accept the money on the grounds that they do not value money. The assassin is hired to eliminate these holdouts who deny the value of money, so that their poverty is not counted in the Elder Brothers' survey.

One of his targets prefers the social recognition and newfound power of his position to the money: "If I took their money, they wouldn't beg me anymore; having rich people plead with me feels great." Another one of the assassin's targets, a painter, argues that his art is predicated on his poverty: "If I became a millionaire overnight, my art would die." These sentiments contrast with the pronouncements of the rich, who, in denial of the coerced nature of their actions, hand out money to the poor saying, "Our money is clean! Our money drove social progress, society should thank us!" Their selfrighteous claim to be "eliminating poverty" sounds hollow even without considering that whoever refuses the money will be killed.

In the end, the assassin is moved to make a new contract with the painter to kill his rich employers. He accepts no money for the job, saying instead

30. "Shanyang renlei" (Taking care of Humans), in Liu Cixin, Xiangcun jiaoshi (Village Schoolteacher), op. cit. 
that one painting that he bought for a pittance is compensation enough. It would be remiss to ascribe a single meaning to the painting, a scene of cracked yellow earth on which rests a desiccated skull, one eye socket containing a living eye that stares skyward, the second socket holding a fresh green plant, flowering vividly against the barren landscape. Yet its symbolism certainly suggests the tenacity of life and a potential for renewal. The final scene, after the assassin has killed the poor and rich alike, echoes this sense of a new life rising out of ruins. As the protagonist and others accept their fate at the hands of the Elder Brothers:

They used three crystal ash trays to support a large silver basin used for holding liquor and ice, and added water to the basin. Then they lit a fire underneath the basin with hundred-yuan notes. They all took turns adding hundred-yuan notes to the fire, and watched spellbound as the flames danced between yellow and green as if alive. The water began to boil when they had burnt one million three hundred and fifty thousand yuan.

This final scene nods toward the primacy of basic physical needs over socioeconomic constructs and the contradiction between use value and exchange value. As in "Taking Care of God," here, too, capitalism is a construct, not a law of the universe and not the end of history. Through its depiction of ruthless plutocrats murdering penniless scavengers to maintain their opulent lifestyles, the story emphasises the contrast between the absolute resources of the world, the social distribution of that wealth, and the way that the system of money affects our behaviour. The human fixation on money is strange, as emphasised by the absurdity of counting out 13,500 hundred-yuan notes as they are thrown on the fire. The exchange value of the money needed to boil the small basin of water for ramen drives home money's inherent lack of use value; it is just a coincidence that we place the value that we do on those pieces of paper, and society need not always be that way.

\section{Discussion}

This pair of short stories, set in the same fictional universe a few years apart, provides four images of civilisation, two of aliens and two of earth. "Taking Care of God" speaks more to the particular concerns of China, as it focuses on contemporary life in rural China and reflects how the socialist ideal of human liberation has morphed into mere consumption, and how traditional Confucian morals such as filial piety come into conflict with the currents of modern society. The God civilisation serves as a foil, bringing into question materialist goals and the possibility of socialist utopia, for although the Gods achieved a utopia that may tentatively be called socialist from the little information given - a post-scarcity, collectivist paradise where all were "absolutely equal, and any one of them could represent all" - they lack true freedom, for they remain confined to their spaceships and bound to the laws of the universe and demands of survival.

In "Taking Care of Humans," the picture of humanity is one emphasising global interconnectedness, where characters identify by social class rather than by state or nation, and serves to highlight the inequities of wealth distribution in the current system. The Elder Brothers depict an extreme development of these tendencies of capitalist society, which have made considerable inroads in China since the reforms, and the story suggests in its place a society characterised by more equitable distribution of resources.
As the stories illustrate the negative consequences of capitalist tendencies in the contemporary world, a space for utopian imagination is created through their critical presentation of the human social system as dynamic and mutable, a contingent product of human action rather than immutable law. The only laws that society must observe are those of the physical universe. This scientific outlook combined with the concern for human welfare may be seen as a continuation of the modern Chinese utopian tradition of thinkers such as Kang Youwei, Liang Qichao, and Mao Zedong, who despite their many differences shared the basic convictions that modernisation itself was not an ends but a means toward an ethical world, which could and would be built upon scientific principles. Whereas those thinkers were first concerned with the future of China as a nation, Liu, writing in an age when China has merged with the international order and achieved wealth and power, foregrounds concerns that resonate not only in China, but all around the world.

We should note that, unlike many other contemporary dystopian tales that involve only human civilisation, Liu's fictions depend on the introduction of an extraterrestrial agent to spark change on earth. This does not imply that external intervention is necessary, however. To the contrary, the alien societies both provide examples of civilisations that, having reached a breaking point, changed from within. The societies depicted are not radically different from our own; even the Gods' may be seen as a form of social democracy.

The stories, like the God Civilisation's spaceships, shine critical light on the problems of contemporary Chinese society, exposing the abandonment of socialist ideals, privatisation of resources, accumulation of wealth and the continuing material struggle of the poor majority, and the social and ecological problems caused by these phenomena. Even as they emphasise the systemic nature of the problems, they show that the system is contingent, not absolute, and they express a utopian hope that human society can be changed for the better. The enduring potential for change, presented as a universal constant in "Taking Care of God," also manifests in the stories' form. "Taking Care of God" ends with humans rethinking their future in light of what they've learned from the Gods. "Taking Care of Humans" ends with a hopeful new beginning in the ruins of the old society. As both stories eschew determinate conclusions in favour of ending with the promise of future change in directions hinted at but uncertain and ultimately open, they resist the necessity of narrative closure. By refusing to choose one future and hence close off myriad alternatives, these stories exemplify the task of the utopian text that, as Jameson writes, is not to represent or produce utopia itself through an idealistic conclusion or synthesis of competing desires, for "that is a matter for human history and collective praxis. It is supposed only to produce the requirement for the synthesis, to open the space into which it is to be imagined." (31)

\section{Adrian Thieret is a PhD candidate in modern Chinese literature at Stanford University. \\ Department of East Asian Languages and Cultures, 521 Memorial \\ Way, Knight Building, Stanford University, Stanford, CA 94305 \\ (thieret@stanford.edu).}

31. Fredric Jameson, Archaeologies of the Future, op. cit., p. 409. 